\title{
Sediments and sedimentary history of Lake Attersee (Salzkammergut, Austria)
}

Ahmad-Reza Behbehani ${ }^{1}$, Jens Müller ${ }^{2}$, Roland Schmidt ${ }^{3}$, Jürgen Schneider ${ }^{1}$, Heinz-Gerd Schröder ${ }^{4}$, Ines Strackenbrock ${ }^{1}$ \& Michael Sturm ${ }^{5}$

'Institut für Geologie und Dynamik der Lithosphäre, Goldschmidtstraße 3, D-3400 Göttingen, FRG

${ }^{2}$ Lehrstuhl für Geologie, Technische Universität München, Lichtenbergstraße 4, D-8046 Garching, FRG

${ }^{3}$ Institut für Limnologie der Österreichischen Akademie der Wissenschaften, Gaisberg 116, A-5310 Mondsee, Austria

${ }^{4}$ Institut für Seenforschung und Fischereiwesen, Untere Seestraße 81, D-7994 Langenargen, FRG

${ }^{5}$ EAWAG-ETH Zürich, Überlandstraße 133, CH-8600 Dübendorf, Switzerland

Keywords: lake sediments, late- and postglacial history, palynology, biogenic carbonate production, eutrophication, heavy metals

\begin{abstract}
Attersee represents a good example of a lake situated in the Northern forelands of the Northern Calcareous Alps and influenced by different sediment-supplying processes during the postglacial. Several compounds, of different origin, form the sediments of the basin. Clastics which are mainly composed of dolomites derive from the Northern Calcareous Alps. Clastic input of organic and inorganic particles is accomplished by rivers and landslides. They are responsible for the main input of siliciclasts like quartz, feldspar and mica. A high proportion of the sediment results from autochthonous biogenic carbonate precipitation. In the shallow sublittoral areas of the northern part of the lake benthic decalcification caused by encrusting macroand micro-phytes is dominant, while in the southern and central parts of the lake epilimnetic decalcification caused by the blooming of phytoplancton is more important during summer. The total biogenic calcium carbonate production reaches about 11000 to 12000 metric tons a year.

Nutrients and residues of cyanophytes (Oscillatoria rubescens) deriving from the eutrophic lake Mondsee were washed into lake Attersee by the Mondseeache. High amount of phosphorus in the sediments of the southern basin depicts local eutrophication in the mouth area of the Mondseeache. The average sedimentation rate in lake Attersee can be determined by different dating methods. Sedimentation rates increased during the last 110 years from $1 \mathrm{~mm}$ a year to $1.8-2 \mathrm{~mm}$ a year as a result of human activities. Five main phases in the postglacial sedimentary history can be recognized: Würm moraines and finely banded varves (before 13000 B.P.), the early Attersee stage (from 13000 B.P. up to 1200 B.P.), and the later Attersee stage after the Bavarian colonization (from 1200 B.P. on). Using heavy metal and isotope analyses the sedimentary history can be reconstructed in more detail for the last 100 years.
\end{abstract}

\section{Introduction}

Sediments and their sites of generation and deposition are part of the exogenous system in the marine and terrestrial region. Because of their size and well defined morphology lakes are suitable areas for the investigation of recent sediments and their genesis. The genesis and amount of autochthonous carbonates, the input and distribution of clastic material, as well as human impact on the lake environment were investigated in lake Attersee.

\section{Location, geography and geology}

Lake Attersee is located in Austria about $40 \mathrm{~km}$ east of Salzburg in front of the Northern Calcareous Alps (altitude: $469.2 \mathrm{~m}$ above Adriatic Sea, 


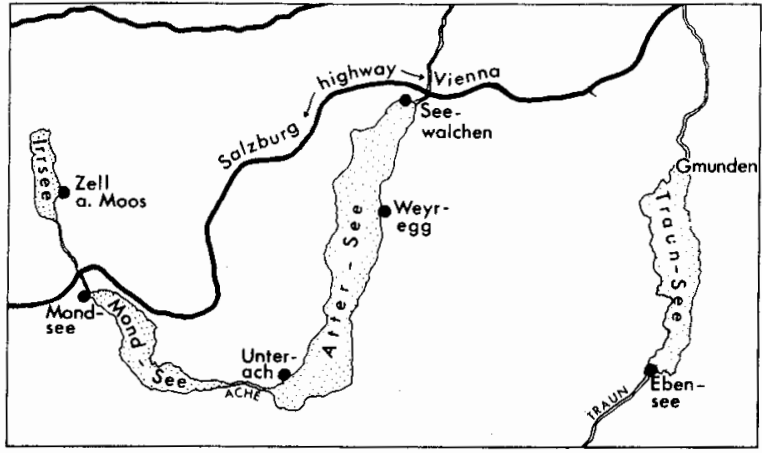

Fig. I. Location map.

length: $20.1 \mathrm{~km}$, mean width: $2.4 \mathrm{~km}$, surface area: $45.9 \mathrm{~km}^{2}$ length of coast: $53 \mathrm{~km}$ ). The Attersee is the largest lake in the Salzkammergut-region. The Mondseeache draining from the eutrophic Mondsee into the oligotrophic Attersee, is the main Atter- see inflow (more than $50 \%$ of the total incoming drainage, see Jagsch, 1971 and Moog, 1981). The only Attersee outlet is the river Ager, which flows towards the river Traun.

The Attersee basin is characterized by a threefold division (Fig. 2, compare Müller \& Simony, 1985):

a. a southern basin $(-170 \mathrm{~m})$ which is separated by a rise from the central and northern part of the lake,

b. a morphologically heterogenous central part with deeper areas $(-160 \mathrm{~m})$ and a submarine rise to $49 \mathrm{~m}$ water depth (Laichberg),

c. a northern basin flattening to the North with a maximum depth of $130 \mathrm{~m}$.

The topographic framework of lake Attersee area was formed during the last sequence of Alpine orogenesis in the Pliocene (Spengler \& Pia, 1924; Schadler, 1959; Janoschek, 1964). During the period of Quaternary glaciation the Attersee region was influenced by three glacial advances of the Traun

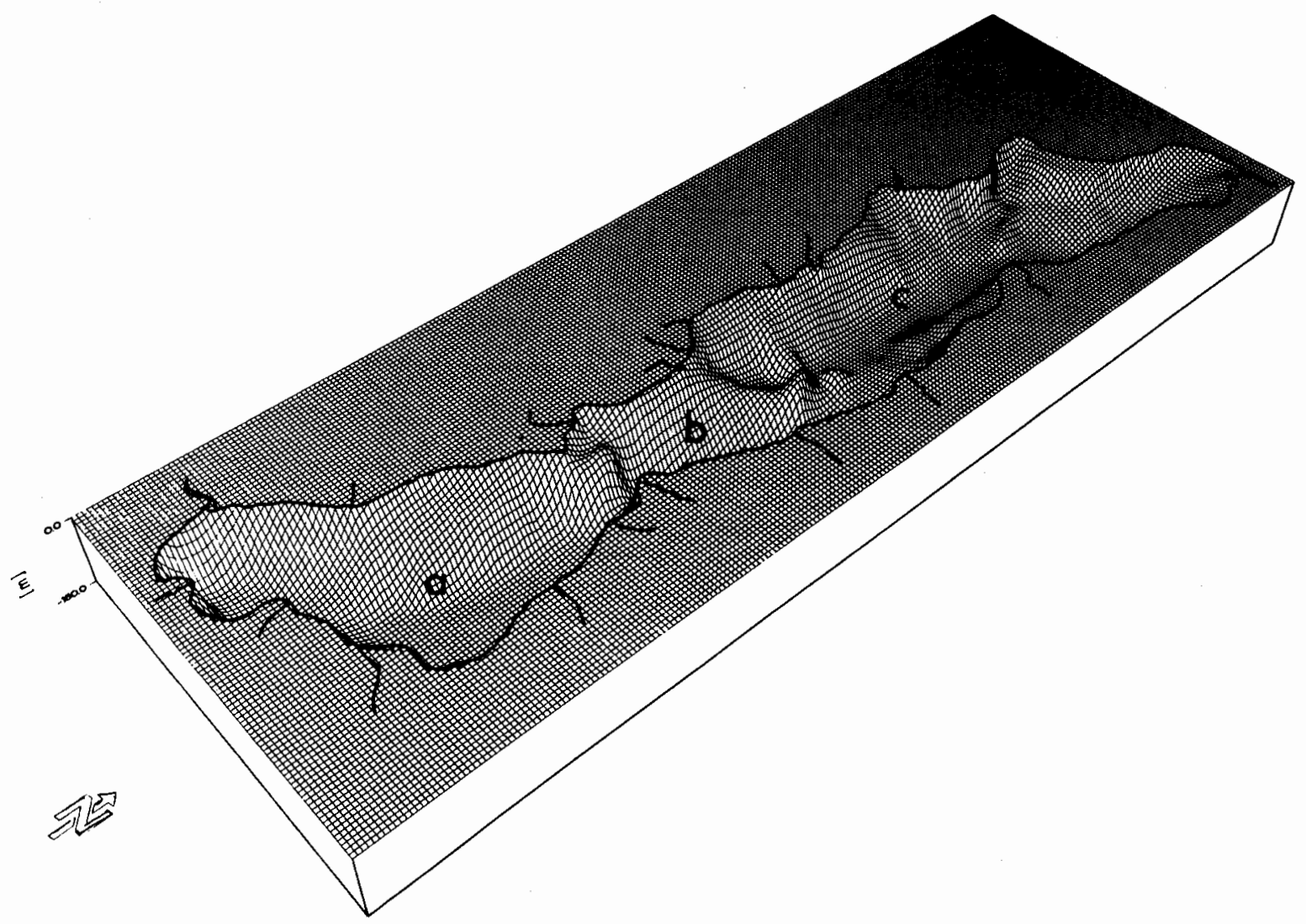

Fig. 2. Attersee basin, 3 dimensional computer graph (a-c: 3 main basins). 


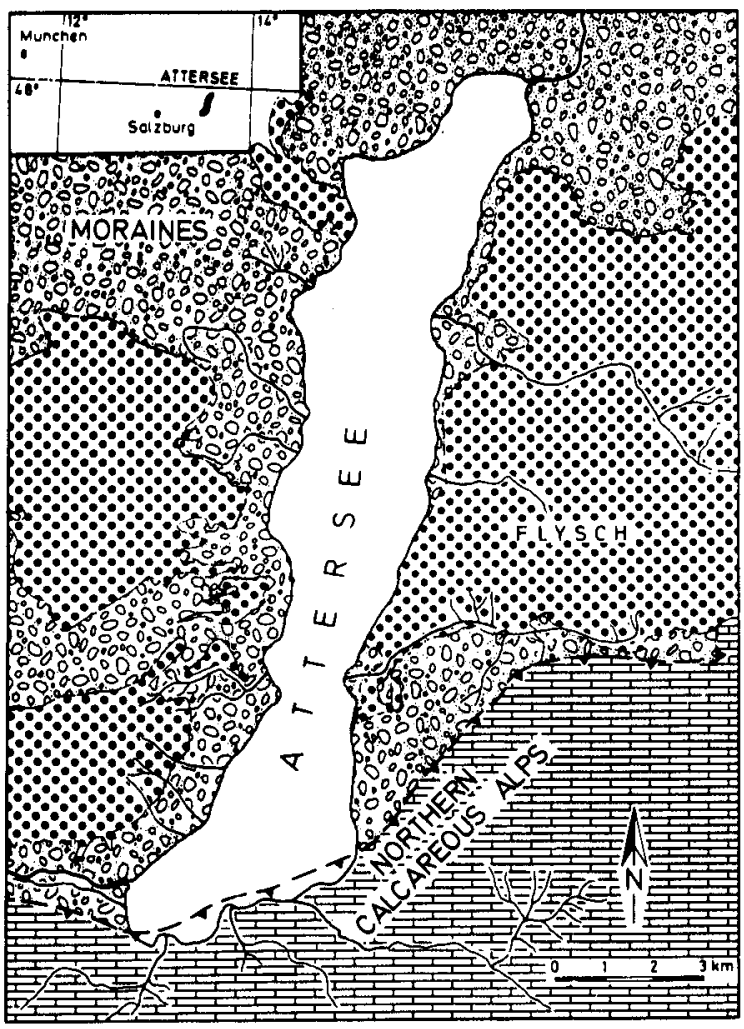

Fig. 3. Geological sketch map of the Attersee region (after Häusler \& Schwarzenböck, 1970).

glacier system. The motion of the glacier modified the basin morphology and formed the moraine ramparts of Mindel, Riss and Würm (Weinberger, 1955; Del Negro, 1969). The Attersee basin was finally shaped during the Würm glaciation. The overdeepened basin was filled with water and sediments during the last ice retreat.

The geological setting of the Attersee is divided into three main tectonic units (Fig. 3):

a. The Northern Calcareous Alps in the South

b. The flysch zone in the east

c. The moraine mounds in the North and West

The character of the lake Attersee shoreline is determined by its geological environment. Hence, there are steep banks in the southern and eastern areas of the Attersee whereas in the southern and western parts the slope angles of the shoreline are gentle and "shelf-like".

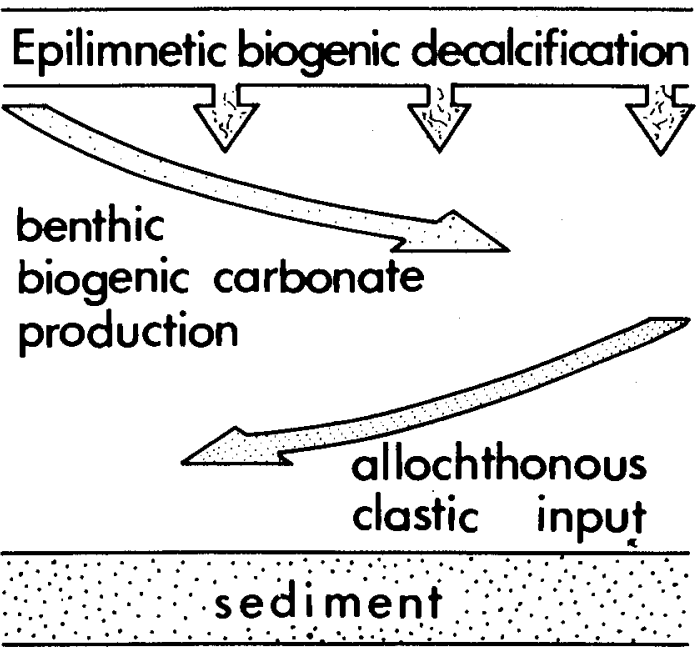

Fig. 4. Sediment supply processes in the Attersee.

\section{Sediment supplying processes and distribution of sediments}

Generally three sediment supplying processes can be distinguished for lake Attersee (Fig. 4)

1) autochthonous carbonate production by biogenic epilimnetic decalcification

2) autochthonous carbonate production by biogenic benthic decalcification (see section 4)

3) allochthonous input to the lake from different source areas.

The input of allochthonous clastic material is accomplished principally by river influx. Besides the rivers, the allochthonous sediment particles are transported into the lake by landslides and mud flows (especially on the eastern bank of the Attersee), by bank erosion in the wave zone and by surface waters, groundwater, rain and wind.

\section{Composition of the sediments}

The mineralogical character of the suspended matter in the rivers draining into Attersee is determined by the different lithologies in each catchment. Dolomite is transported into the lake from the Calcareaous Alps, whereas quartz, feldspars (albite and microcline), clay minerals (kaolinite, illite, montmorillonite) and micas (chlorite and muscovite) derive from the flysch and moraine areas. 

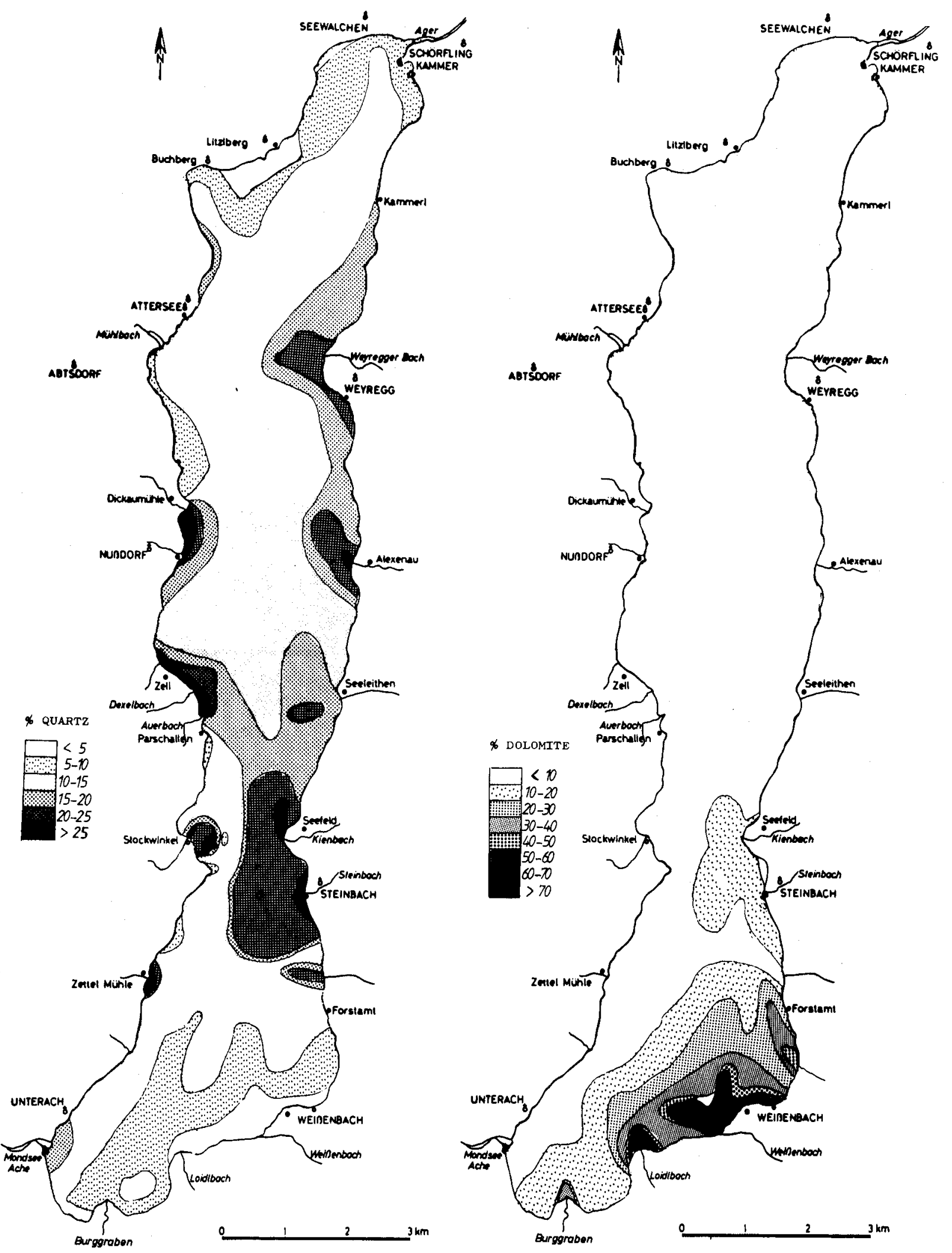
The influence of the different source areas on the composition of the Attersee sediments is clearly shown by mapping the surface sediments (Fig. 5).

\section{Sediment distribution mechanisms}

The distribution mechanisms of the allochthonous clastics depend on the nature of the minerals (size, shape, density), the physical chemical parameters of the water-body and the lake basin morphology.

From May to October vertical differences in the water column of Attersee are caused by thermal stratification. This water layering has a considerable influence on the distribution mechanisms of the allochthonous sediments. A distinction was made between suspended sediment transported by over, inter and underflows (Fig. 6, Sturm \& Matter, 1978; Lambert, 1976).

The occurrence of over and interflows depends on the temperature stratification of the waterbody whereas the occurrence of underflows and turbidity currents is not bound to temperature stratification. The sedimentary structures produced by turbidites and underflows (e.g. graded beds etc.) are very similar and cannot be traced back to their processes of origin.

\section{Landslides on the eastern shore}

The flysch mountains east of lake Attersee are particularly susceptible to landslides and mud flows because of their morphology and geology. They are composed of clayey to sandy sedimentary rocks and rise steeply from the shoreline of the lake.

The high frequency of mud flows into the Steinbach valley results from the presence of the overthrust zone of the Northern Calcareous Alps above the flysch zone (Janoschek, 1964). Sediment material deriving from these landslides can be found in the Attersee sediments by a well-placed core sampling (Chondrogianni \& Schmidt, 1984; Strackenbrock, 1985).

\section{Carbonate production and -sedimentation}

The biogenic carbonates in lake Attersee are produced by two different processes: biogenic epilimnetic decalcification and biogenic benthic decalcification (Fig. 7).

\subsection{Biogenic epilimnetic decalcification}

During the summer months the increasing assimilation activities of blooming phytoplankton

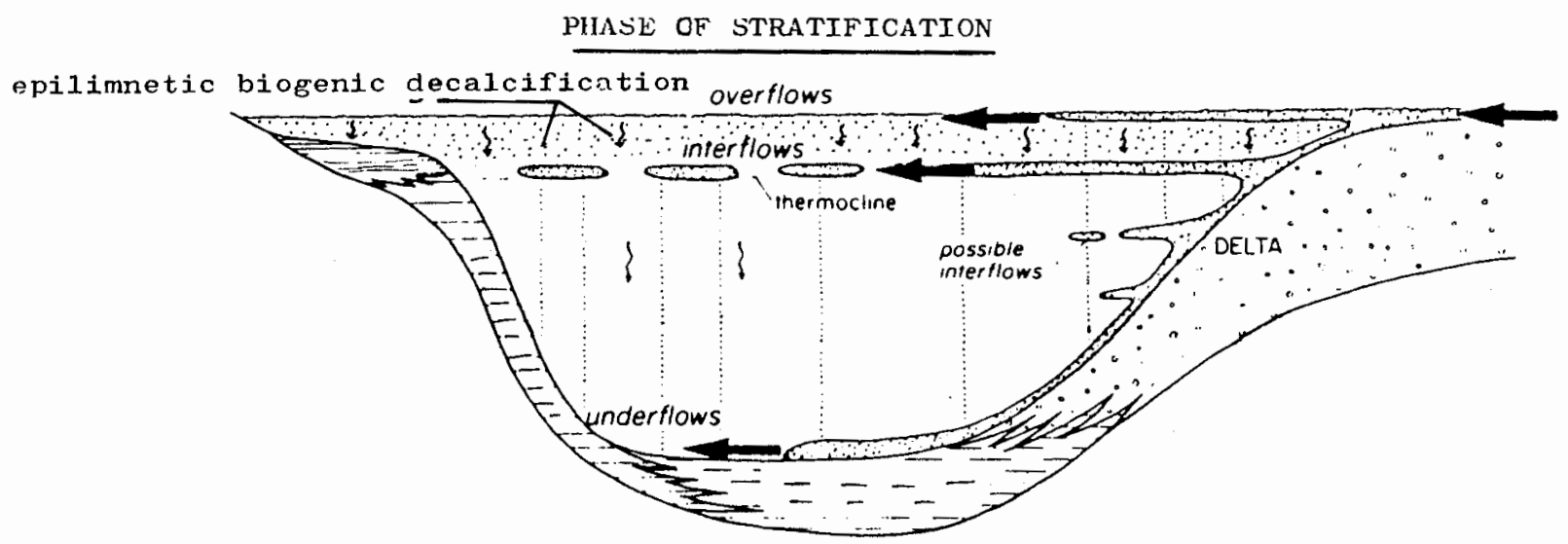

Fig. 6. Distribution mechanisms of allochthonous and autochthonous sediment particles in a lake under thermal stratification conditions (modified after Sturm \& Matter, 1978).

Fig. 5. The distribution of index minerals according to the source areas is well documented within the uppermost $5 \mathrm{~cm}$ of the surface sediments (mapping after Niessen, 1981; Chondrogianni \& Schmidt, 1984; Behbehani, 1984; Strackenbrock, 1985). 


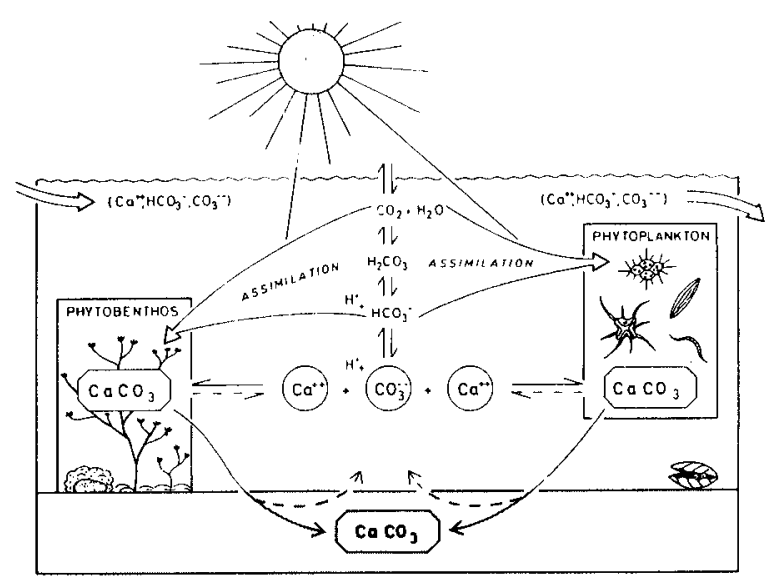

Fig. 7. Scheme of the hydrochemical/biological carbonate precipitạtion (from Schröder, Windolph \& Schneider, 1983).

cause intense consumption of $\mathrm{CO}_{2}$ and $\mathrm{HCO}_{3}{ }^{-}$in the epi- and metalimnion (0-20 m water depth). Due tồ these biological activities the water becomes highly oversaturated with respect to $\mathrm{CaCO}_{3}$ and calcite is precipitated (Nipkow, 1920; Minder, 1922; Ruttner, 1947, 1962; Schöttle \& Müller, 1968; Kelts \& Hsü, 1978; Schröder \& Schneider, 1980; Schröder, Windolph \& Schneider, 1983). Within the Attersee area of $45.9 \mathrm{~km}^{2}$ the epilimnetic biogenic decalcification produces about 6500 metric tons of $\mathrm{CaCO}_{3}$ a year.

\subsection{Biogenic benthic decalcification}

The precipitation of $\mathrm{CaCO}_{3}$ in the shallow sublittoral area ( 0 to about $12 \mathrm{~m}$ water depth) is due to the $\mathrm{CO}_{2}$ and $\mathrm{HCO}_{3}^{-}$assimilation of micro-, macro- and epiphytes. In the northern part of lake Attersee large parts of the sublittoral zone are covered by rounded and mostly flattened stones and gravels of morainic material. These gravels and stones (limestones, dolomites, sand and siltstones, mostly from glacial till) form the substrate for microphytes which produce calcareous crusts (Fig. 8). In between the stones, macrophytes (mostly charophytes) grow on muddy sediments (Fig. 7/8). These macrophytes form the living substrate for epiphytes which together with the macrophyte host plant produce calcareous overgrowths.

The crusts and overgrowths are destroyed by storms and waves and then contribute to the sedimentation of lake marl within the shallow sub-

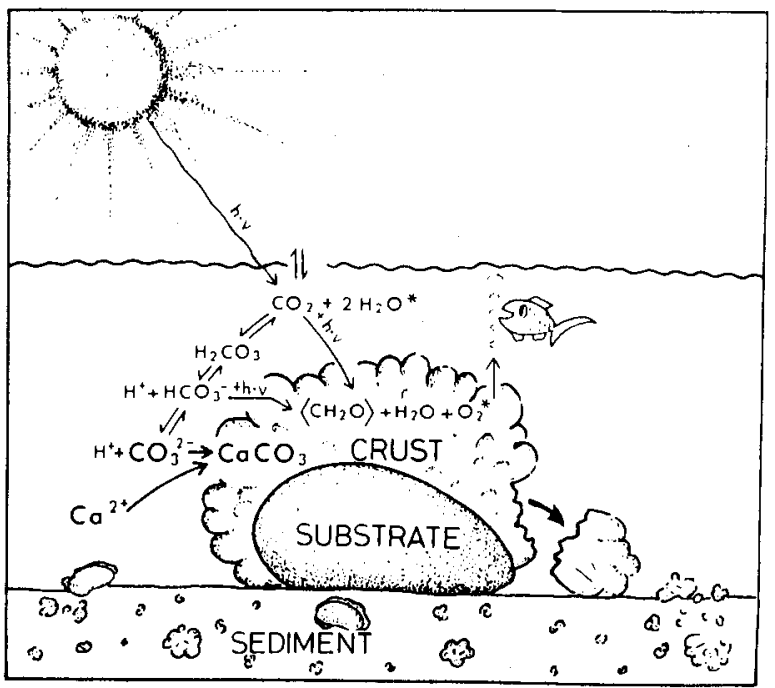

Fig. 8. Construction of lacustrine crusts and their contribution to the formation of sublittoral sediments (after Schneider \& Schröder, 1980).

littoral zones as well as to the sedimentation of marly muds in the deeper zones (Fig. 9, Schäfer, 1973; Schäfer \& Stapf, 1978). On a sublittoral area of $1.3 \mathrm{~km}^{2}$ benthic biogenic decalcification produces about 5000 metric tons of $\mathrm{CaCO}_{3}$ a year. The whole biogenic calcium carbonate production is calculated as 11000 to 12000 metric tons a year or 250 metric tons per $\mathrm{km}^{2}$ a year (Schröder, Windolph \& Schneider, 1983).

\section{Eutrophication}

Most of the nutrients that reach lake Attersee are washed in by the river Mondseeache flowing from

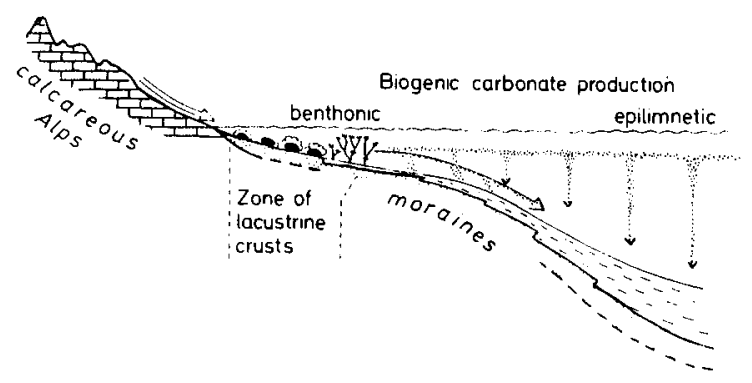

Fig. 9. Carbonate production and sedimentation in lacustrine environments (from Schneider, Schröder \& Le CampionAlsumard, 1983). 
lake Mondsee into lake Attersee (more than 50\% of the total phosphorus load, Müller, 1979b). Lake Mondsee was characterized by eutrophication and massive bloom of Oscillatoria rubescens until recently. These cyanophytes were regularly washed into the Attersee by the river Mondseeache and caused a slight eutrophication of the southern part of Attersee. Consequently an increasing development of phytoplankton occured in the southern part of lake Attersee (Müller, 1979).

The bay of Unterach in the southern basin has become slightly eutrophic (Behbehani, 1984) as indicated by:

1. lower transparency of water within the bay of Unterach,

2. massive grow of the alga Cladophora in front of the mouth of Mondseeache river.

3 . increased growth of submersed plants within the bay.

4. poor colonization by calcifying macrophytes (Characeae),

5. decline in benthic biogenic decalcification

6. existence of Oligochaetes and other organisms within the sediments which can be used as eutrophication indicators

7. allochthonous Oscillatoria filaments within the sediments

8. relatively high amount of organic substances within the sediments

9. high amounts of total phosphorus within the sediments.

Some of the eutrophication indicators can be identified within the surface sediments as well as in deeper parts of sediment cores which represent the fossil equivalent. A comparison of oligotrophic and eutrophic hard water lakes shows that a remarkable development of calcareous crusts (micro- and macrophytes) does not occur in all hard water lakes (Kann, 1940). One reason could be the presence of nutrients like phosphates which can act as inhibitors to calcite nucleation as well as organic substances which can hinder the nucleation of $\mathrm{CaCO}_{3}$ by complexing $\mathrm{Ca}$-ions as known from the investigations of Suess (1970), Chave \& Suess (1970), and Walter \& Hanor (1979a, b).

Fig. 10 clearly shows the decreasing eutrophication/increasing oligotrophic trend in the Attersee from south to north. Investigations by Behbehani (1984) show that calcification of macrophytes is zero in front of the mouth of Mondsee and increases northwards. In the oligotrophic northern part of lake Attersee different types of Charophyta calcification are be found (Fig. 11).

In the southern part of the Attersee the more or less intensive calcification seems to be used as a qualitative indicator of eutrophication. The construction of a central sewage plant and a ring pipe for the Attersee and the Mondsee area should bring about an amelioration in the ecological situation. The increase of water transparency and the decrease of nutrients and of Oscillatoria blooms are the first indicators of success.

\section{Sedimentation rates and sedimentation history}

Several cores were analyzed in order to get information about sediment age and sedimentation rates. Three different dating methods were applied.

\subsection{Pollen analysis}

Because of the late and postglacial floral development it is possible to determine the age of sediments from three cores (Fig. 12). The following boundaries are important horizons:

a. late-glacial decrease of the non arboreal pollen, first occurence and expansion of Juniperus (juniper) and Betula (birch) 13000 B.P.

b. border between late and postglacial time 10000 B.P. (immigration of forest trees)

c. Corylus (hasel) peak of Boreal 8500 B.P.

d. immigration of Fagus (beech) and Abies (fir) during the Older Atlantic period 6500 B.P.

e. first (Neolithic) peak of forest clearance and immigration of Carpinus (hornbeam) 4700 B.P.

f. massive non arboreal pollen increase, colonization phase of the Bavarians in the 8th century A.D. and subsequently from about 1200 B.P.

Paleoclimatic indications from pollen and sedimentological evidence point to the same conclusions: About 6500 B.P. a more humid climate is indicated by the frequency of turbidites (see also Fig. 12 prequaternary pollen). After that time the frequency of pollen increases and simultaneously the frequency of turbidites with a simultaneous increase of pollen concentration occurs before the historical time of the non arboreal pollen peak (1200 B.P.) 


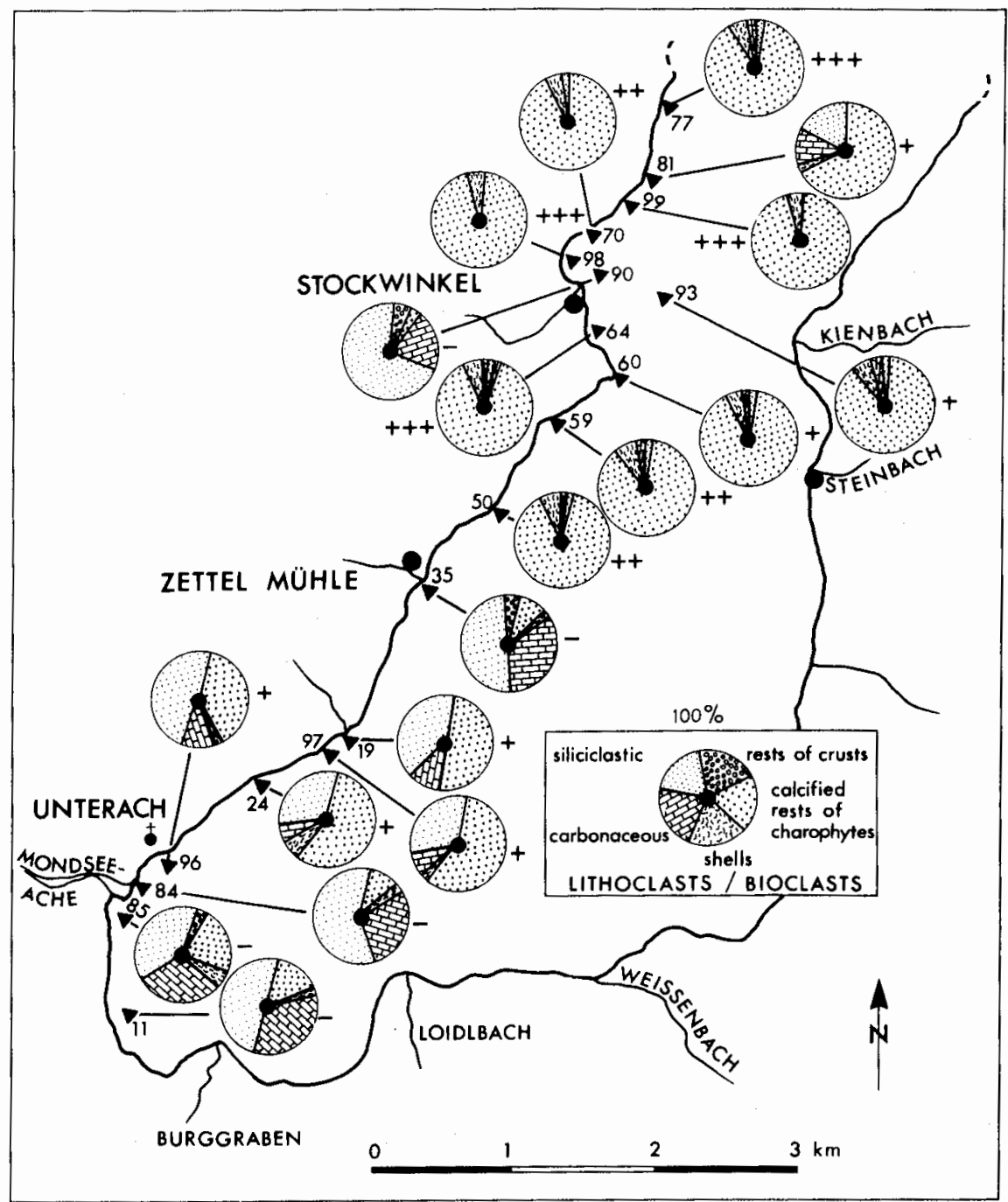

Fig. 10. Decreasing eutrophic/increasing oligotrophic trend in the Attersee from south to north indicated by northward increasing calcification of charophytes (evaluation of the sand-fraction from surface sediments, after Behbehani, 1984).

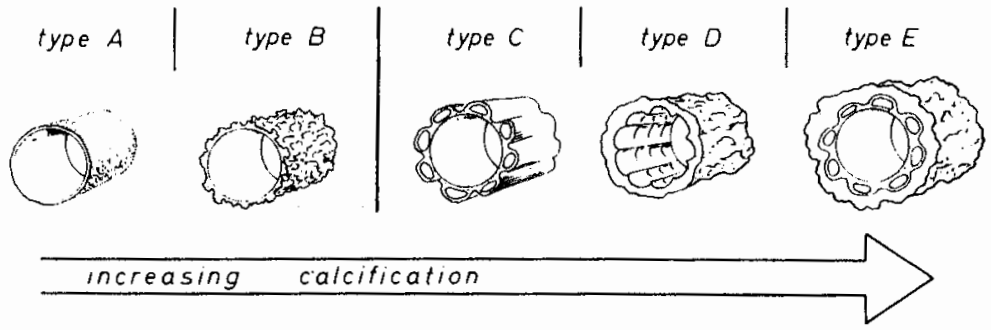

Fig. II. Different types of macrophytes (Charophyta-) carbonate. Type A and B: unstructured stems, Type C-E: structured stems. A without epiphytes, B with epiphytes, C small epiphytic calcification, D strong epiphytic calcification with minor internal calcification, E strong epiphytic and internal calcification (from Schneider, Schröder \& Le Campion-Alsumard, 1983). 


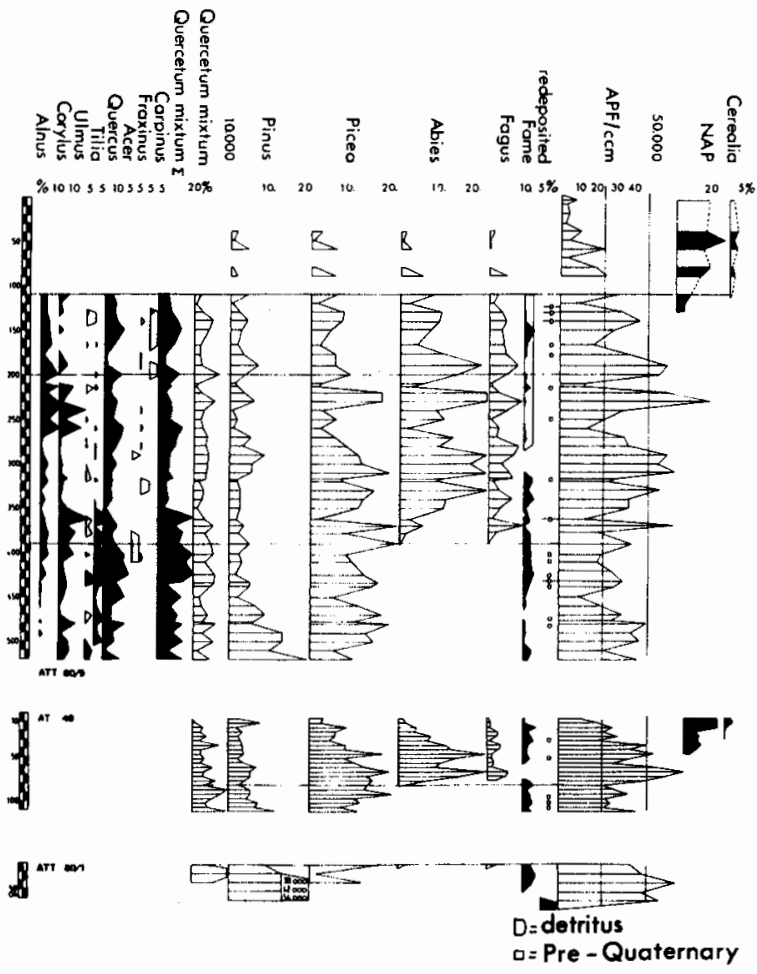

Fig. 12. Pollen analyses from 3 sediment cores (ATT 80/9, AT 48, ATT $80 / 1$ ). NAP $=$ non arboreal pollen, $\mathrm{APF}=$ absolute pollen frequency. For position of the cores see Fig. 17.

\subsection{Heavy metal and isotope analyses}

Since the industrial revolution heavy metals have become characteristic components in recent sediments. It is possible to correlate the enrichment of heavy metals in sediments with historically dated events.

Increased $\mathrm{Zn}$ (3.1 fold), $\mathrm{Cd}$ (5.6 fold) and $\mathrm{Pb}$ (1.9 fold) contents were observed in the upper $20 \mathrm{~cm}$ of the sediment column of lake Attersee (see Fig. 13). ${ }^{210} \mathrm{~Pb}$ dating designates $1870-1880$ as the initial stage of heavy metal pollution originating from anthropogenic sources (Fig. 13). ${ }^{137} \mathrm{Cs}$ dating designates $1960-1965$ as the stage of maximum enrichment originating from the atmospheric atomic bomb tests (1963 test stop treaty; Fig. 13).

\subsection{Slag enrichments}

Slag particles in the lake sediments indicate coal and oil combustion by vessels on lake Attersee. A steamship line was first established in 1869 (Siakala, 1979). Between 1947 and 1958 diesel and electri- cally driven ships took the place of the steamboats. The slag particles occur above $20 \mathrm{~cm}$ sediment depth in the southern profundal zone as well as on the carbonate shelf in the North and reach their maximum concentration between $9 \mathrm{~cm}$ and $5 \mathrm{~cm}$ depth. The contents of slag particles decreases towards the sediment surface. Hence, the average sedimentation rate in the profundal zone of the Attersee amounts to about $2 \mathrm{~mm} / \mathrm{a}$ within the last 100 years.

From these dates it is possible to reconstruct sedimentation rates in the Attersee:

1. The oldest documented stage in the north $(13000-12000$ B.P.) is characterized by small average sedimentation rates of $0.17 \mathrm{~mm} / \mathrm{a}$.

2. The average sedimentation rate is $0.3 \mathrm{~mm} / \mathrm{a}$ from the beginning of the medieval phase of forest clearance (NAP rise 1200 B.P.).

3. During the last 100 years the sedimentation rate has increased to $2 \mathrm{~mm} / \mathrm{a}$.

The increasing sedimentation rate can be explained either by a changing allochthonous clastic input (e.g. increasing erosion through agricultural activity) or by a changing autochthonous carbonate production. It is also possible that both processes have accelerated.

\section{Results: Sedimentary history of the last 15000 years}

The postglacial history (after Würm glaciation) of the Attersee was investigated on the basis of sediment cores along a profile across the lake, sediment echography (ORE, $3.5 \mathrm{kHz}$ ) and by mapping the sediment types (see Figs. 14-17). Five main phases in the sedimentary history were clearly recognized by means of the sedimentological studies (see Fig. 17 and 18):

a. Würm moraines with glacially striated pebbles within glacial flour (see Fig. 17)

b. Finely banded varves formed during the alpine arctic lake stage before 13000 B.P. (Fig. 17)

c. From 13000 B.P. on: the Attersee stage with well developed epilimnetic and benthic carbonate production which is represented by higher carbonate contents (Fig. 17). Pollen Analyses (see Fig. 12) and sedimentology allow the recognition of finer subdivision into individual events. In the basin sediments and on the shelf different segments 

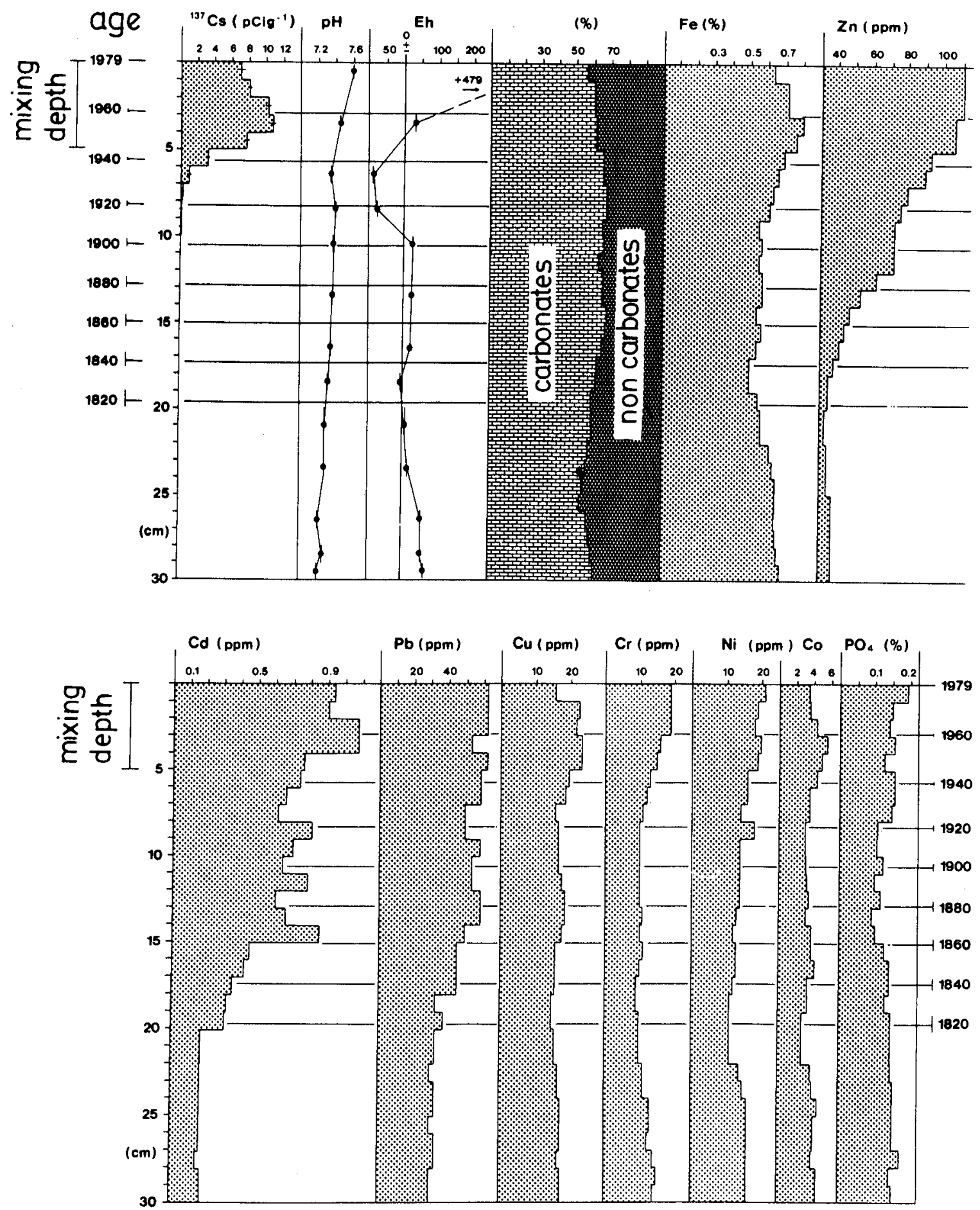

Fig. 13. Vertical distribution of carbonate content, heavy metals, ${ }^{137} \mathrm{Cs}$ and $\mathrm{PO}_{4}$-concentrations within the core AT 1 (northwestern shelf of Attersee). $\mathrm{pH}$ and $\mathrm{Eh}$ were measured within the first hour after sampling. Time scale was calculated assuming a constant sedimentation rate (from Müller, Dominik, Schröder \& Schneider, 1983). 


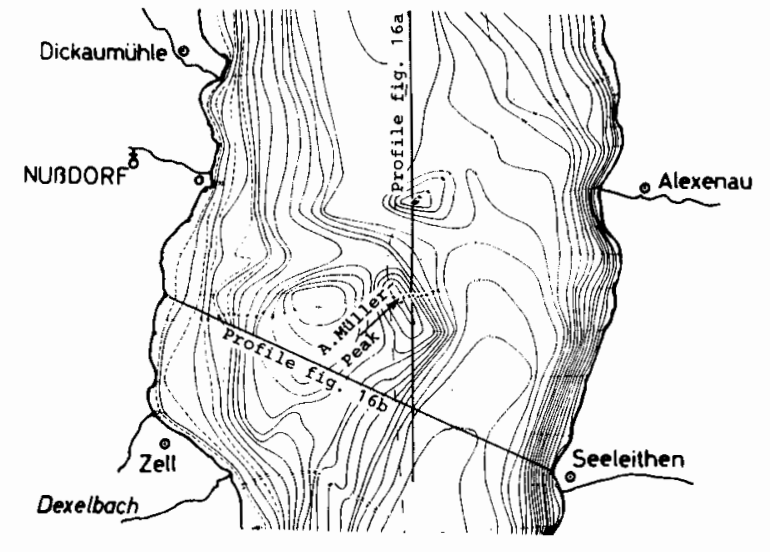

Fig. 14. Map of the central part of Attersee showing the position of the sediment echography profile of Fig. 15.

with increased or decreased turbidite activity can be identified by pollen analysis from 13000 to about 1200 B.P. (Fig. 17).

d. From 1200 B.P. on: the Attersee stage shows increased sedimentation rates and lower carbonate contents (Fig. 17) after forest clearance as a consequence of the Bavarian colonization. e. During the last 100 years the sedimentation rate further increases and the sedimentary history can be reconstructed in more detail using heavy metal and isotope studies as well as slag particles from steamboats (see section 9.2, 9.3, Fig. 13).

The rough time scale of the first four phases is verified by pollen analyses, ${ }^{14} \mathrm{C}$ dating, sedimentology and sediment chemistry and is even macroscopically visible in sediment cores. The fifth phase of the last 100 years can be dated much more precisely by heavy metal and isotope studies (see section 6). Comparison of sediment cores from other parts of the Attersee and other lakes in the northern alpine foreland (see e.g. Müller \& Schmidt, 1985) show that this rough chronology is also regionally applicable.

\section{Acknowledgements}

The investigations were supported by grants of the "Deutsche Forschungsgemeinschaft" (DFG AZ: Schn $16 / 8$ to $12-1$ ). We thank Prof. Dr. F. Oldfield (Liverpool) for critically reading the manuscript.

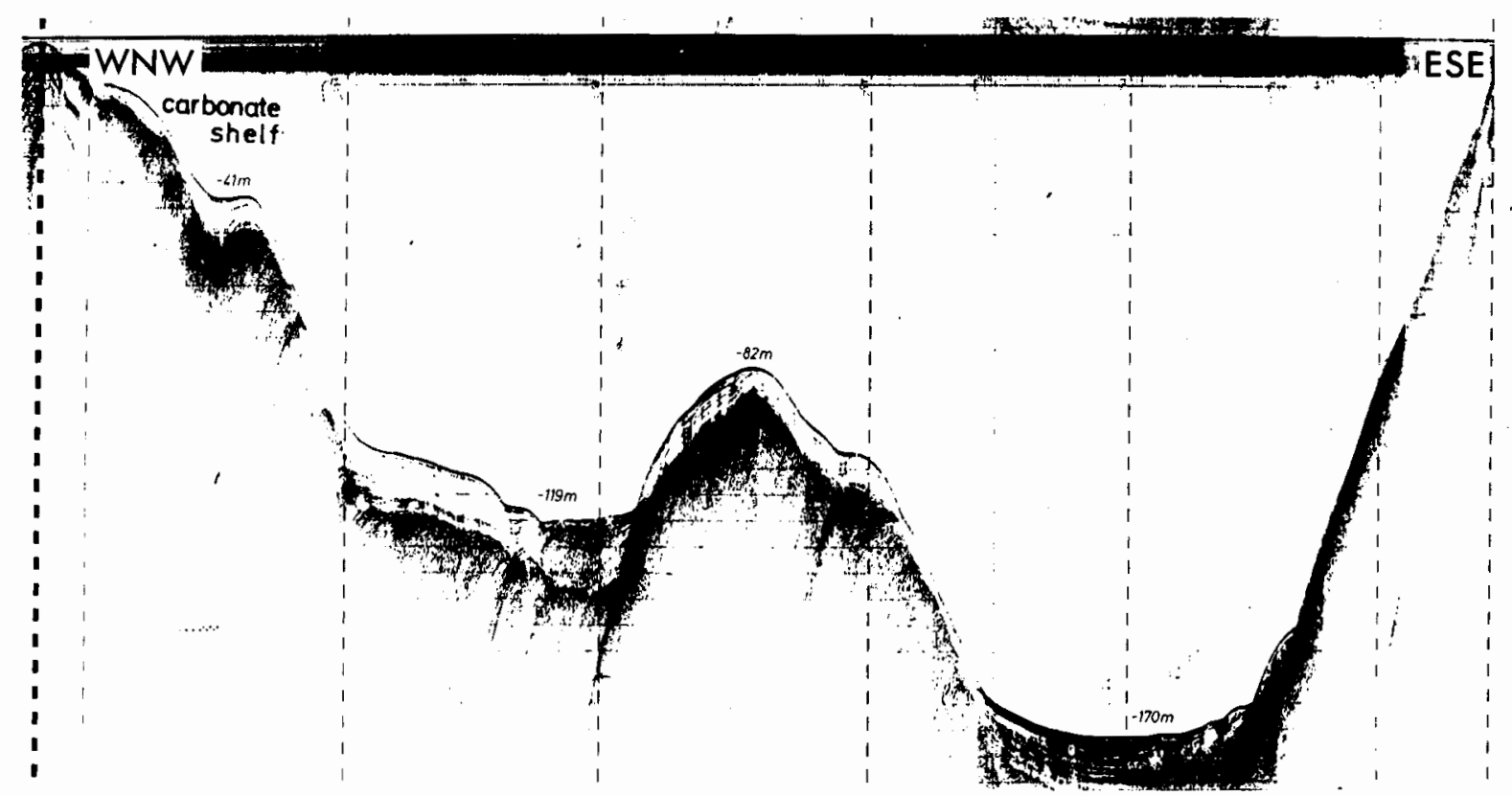

Fig. 15. Sediment echography (ORE, $3.5 \mathrm{KHz}$ ) showing the different sediment thickness in the basin respectively on the ridge and on the shelf region. 


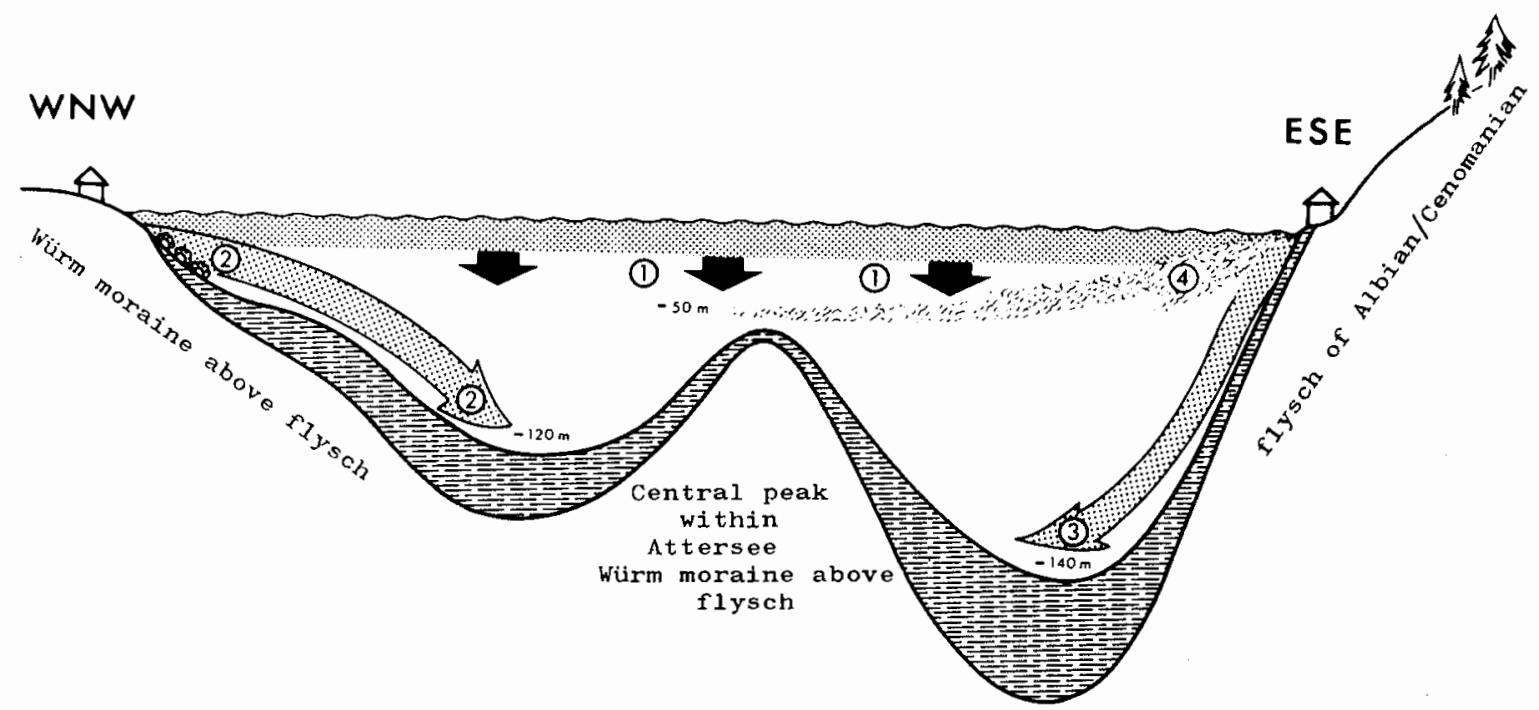

Fig. 16. Model of the different influences of the sediment contributing processes within the central part of lake Attersee.

$1 \mathrm{CaCO}_{3}$ from the epilimnetic biogenic decalcification

$2 \mathrm{CaCO}_{3}$ from the benthic biogenic decalcification

3 clastic input of silicates (mostly)

4 sporadic inflow of fine grained sediments during thunderstorms, heavy rain falls, snow break or through land slides

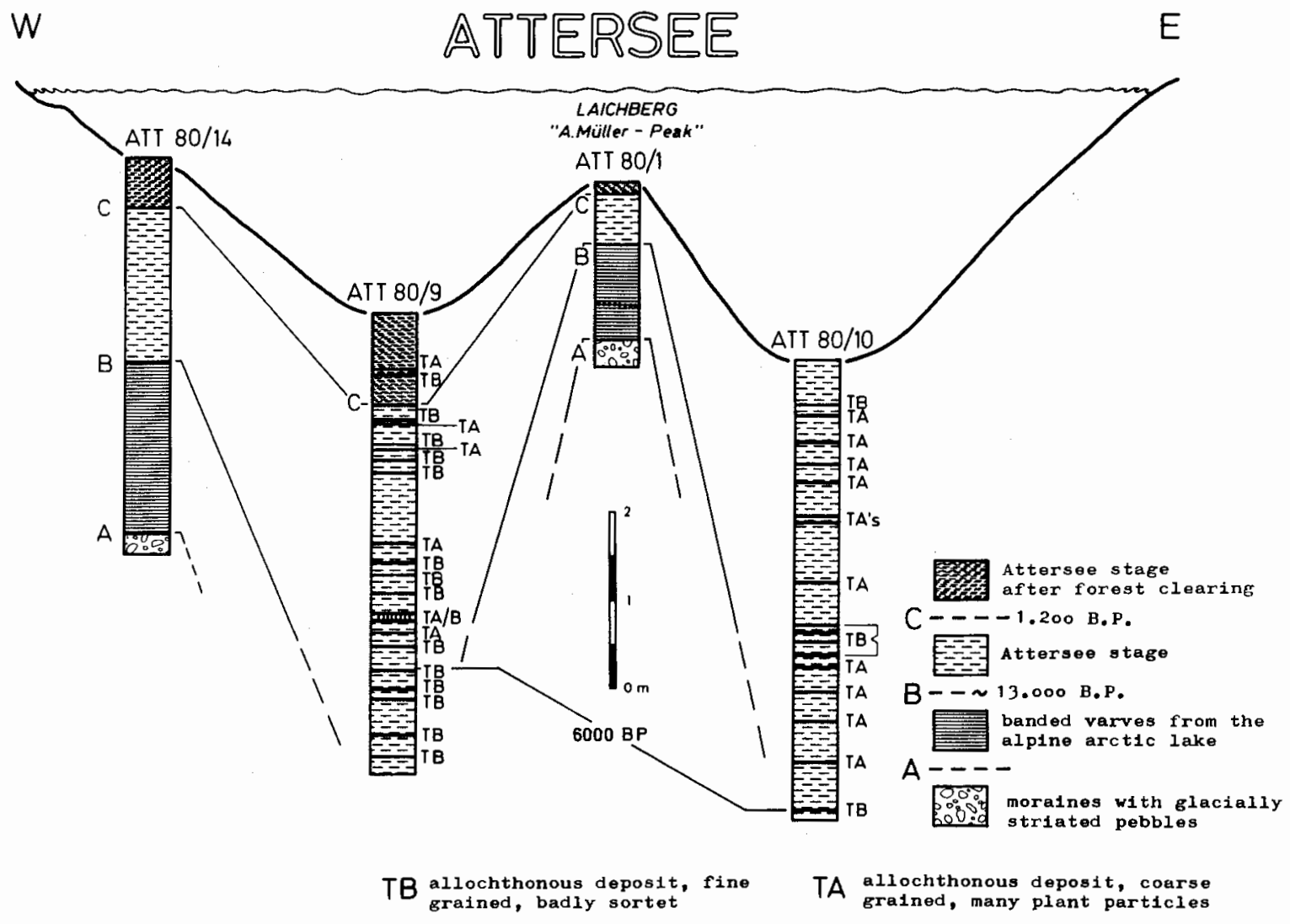

Fig. 17. 4 cores across the underwater ridge ("Armin Müller peak") from the central part of Attersee. The four main phases of sedimentary history are indicated. 


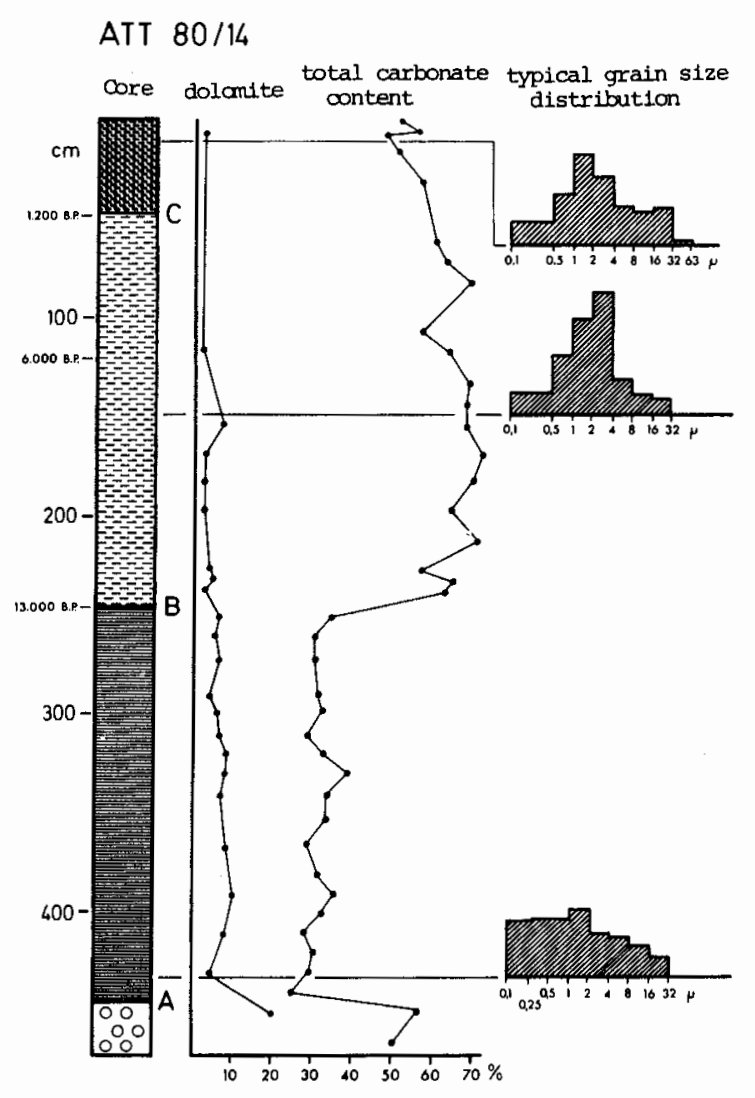

Fig. 18. Sedimentological analysis of a typical core from the shelf region (see Fig. 17). The four main phases of sedimentary history are well indicated by chemical, mineralogical and grain size distribution.

\section{References}

Behbehani, A. R., 1984. Sedimentologische Untersuchungen im südlichen Teil des Attersees (Österr. Kt. 1:25000, Bl. 64/4 Unterach, Salzkammergut, Oberösterreich). Diplome-thesis, Univ. Göttingen, 137 p.

Chave, K. E. \& E. Suess, 1970. Calcium carbonate saturation in seawater: Effects of dissolved organic matter. Limnol. Oceanogr. 15: 633-637.

Chondrogianni, C. \& H. Schmidt, 1984. Sedimentologische Untersuchungen im Attersee-Nordbecken (Österr. Kt. 1:25000, Bl. $65 / 2$ Sankt Georgen im Attergau, Salzkammergut, Oberösterreich). Diplome-thesis, Univ. Göttingen, 208 p.

Del Negro, W., 1969. Bemerkungen zu den Kartierungen $L$. Weinberger's im Traungletschergebiet (Attersee- und Traunseebereich). Verh. Geol. B.-A., Wien, 1969: 12-15.

Golubic, S. \& J. Schneider, 1979. Carbonate dissolution. In: P. A. Trudinger \& D. J. Swanine, (Eds), Biogeochemical cycling of mineral-forming elements. Studies in Environment Science 3, Elsevier, Amsterdam-Oxford-New York: 107-129.
Häusler, H. \& H. Schwarzenböck, 1970. Geologische Karte $1: 50000$, Karte 12. Amt O.Ö. Landesregierung, Abt. Wasserbau, Hydrogr. Dienst, lng. Konsulent Dr. techn. H. Flögl, Linz, Dez. 1969.

Jagsch, A., 1977. Chemische Untersuchungen der wichtigsten Zuflüsse und des Ausrinns im Jahre 1976 und NährstoffFrachtberechnungen, Attersee. Vorläufige Ergebnisse des OECD-Seeneutrophierungs- und des Maß-Programms, 1978: $33-40$.

Janoschek, W., 1964. Geologie der Flyschzone und der helvetischen Zone zwischen Attersee und Traunsee. Jb. Geol. B.A., Wien, 107: 161-214.

Kann, E., 1940. Ökologische Untersuchungen an Litoralalgen ostholsteinischer Seen. Arch. Hydrobiol. 37: 197-269.

Kelts, K. \& K. J. Hsü, 1978. Freshwater carbonate sedimentation. In: A. Lerman (Ed.): Lakes, Chemistry, Geology, Physics. Springer, New York, Heidelberg, Berlin, 295-329.

Lambert, A., K. Kelts \& N. F. Marshall, 1976. Measurements of density underflows from Walensee, Switzerland. Sedimentology 23: 87-105.

Minder, L., 1922. Über biogene Entkalkung im Zürichsee. Verh. Int. Ver. Limnol. 1: 20-32.

Moog, O., 1981. Wasserbilanzierung des Ager-SeenkettenSystems: Stand 1980. Arb. Lab. Weyregg, 5: 43-50.

Müller, G., J. Dominik, H.-G. Schröder \& J. Schneider, 1983. Zur Chronologie anthropogener Schwermetalle in den Sedimenten des Attersees (Österreich). Tschermaks Min. Petr. Mitt., 31: 193-206.

Müller, G., 1979a. Grundlagendaten für Fuschlsee, Mondsee und Attersee sowie das gesamte Einzugsgebiet. Arb. Lab. Weyregg, 3: 10-14.

Müller, J. \& R. Schmidt, 1985. Evolution of postglacial sedimentation in an alpine lake: Funtensee, Northern Calcareous Alps. Z. Geltscherkol. Glazialgeol., 21: 51-57.

Müllner, J. \& F. Simony, 1895. Die Seen des Salzkammergutes. ln: A. Penck \& E. Richter, (Eds), Atlas der österreichischen Alpenseen. Hölzel, Wien.

Niessen, F., 1981. Sedimentologische Untersuchungen vor dem Weißenbach-Delta im Südbecken des Attersees. Diplomethesis, Univ. Göttingen, 124 p.

Nipkow, F., 1920. Vorläufige Mitteilungen über Untersuchungen des Schlammabsatzes im Zürichsee. Schweiz. Z. Hydrol. 1: $100-122$.

Ruttner, F., 1947. Zur Frage der Karbonatassimilation der Wasserpflanzen, 1. Teil: Die beiden Haupttypen der Kohlenstoffaufnahme. Österr. Bot. Z. 94: 265-294.

Ruttner, F., 1962. Grundriß der Limnologie. W. De Gruyter, Berlin, $332 \mathrm{pp}$.

Schadler, J., 1959. Zur Geologie der Salzkammergutseen. In: Flüsse und Bäche im Salzkammergut. Schr. Österr. Fischereiverb. Salzburg, 2: 36-54.

Schäfer, A., 1973. Zur Entstehung von Seekreide Untersuchungen am Untersee (Bodensee). N. Jb. Geol. Pal./Mh. 4: $216-230$.

Schäfer, A. \& K. R. G. Stapf, 1978. Permian Saar-Nahe Basin and recent Lake Constance (Germany): two environments of lacustrine algal carbonates. Spec. Publ. int. Ass. Sediment, 2: 83-107.

Schneider, J., H. G. Schröder \& T. Le Campion-Alsumard, 1983. Algal micro-reefs coated grains from freshwater environments. In: T. M. Peryt, (Ed.), Coated Grains. Springer Verlag Berlin, Heidelberg: $284-298$. 
Schneider, J. \& H. G. Schröder, 1980. Calcification des cyanophycées et leur contribution à la genèse des sédiments calcaires. In: L. Humbert, (Ed.), Cristallisation-DéformationDissolution des carbonates, 17./18. Nov. 1980, Bordeaux: $421-428$

Schöttle, M. \& G. Müller, 1968. Recent carbonate sedimentation in the Gnadensee (Lake Constance) Germany. In: G. Müller \& Friedman (Eds), Recent developments in carbonate sedimentology in Central Europe. Springer, Berlin, 148-156.

Schröder, H. G., 1982. Biogene benthische Entkalkung als Beitrag zur Genese limnischer Sedimente. Beispiel: Attersee (Salzkammergut, Oberösterreich). Diss. Univ. Göttingen, $178 \mathrm{p}$.

Schröder, H. G., H. Windolph \& J. Schneider, 1983. Bilanzierung der biogenen Karbonatproduktion eines oligotrophen Sees (Attersee, Salzkammergut - Österreich). Arch. Hydrobiol., 97: 3-17.

Schröder, H. G. \& J. Schneider, 1980. Hydrochemische Untersuchungen zum Karbonatkreislauf und zur Sedimentationsgeschichte des Attersees. Arb. Lab. Weyregg, 4: 235-257.

Siakala, H., 1979. Wirschaftsgeographie der Randgemeinden des Attersee. Diplome-thesis Geogr. Inst. Wirtsch. Univ. Wien.

Spengler, E. \& J. Pia, 1924. Geologischer Führer durch die Salzburger Alpen und das Salzkammergut. Samml. geol. Führer, 26, Borntraeger, Berlin.
Strackenbrock, I., 1985. Sedimentologische Untersuchungen im mittleren Teil des Attersees. (Österr. Kt. 1:25000, Bl. 64/4 Unterach, Salzkammergut, Oberösterreich). Diplome-thesis Univ. Göttingen, $89 \mathrm{p}$.

Sturm, M. \& A. Matter, 1978. Turbidites and varves in Lake Brienz (Switzerland): deposition of clastic detritus by density currents. In: A. Matter \& M. E. Tucker, (Eds), Modern and Ancient Lake Sediments. Spec. Publ. int. Ass. Sediment., 2: $147-168$.

Suess, E., 1970. Interaction of organic compounds with calcium carbonate. 1. Association phenomena and geochemical implications. Geochim. Cosmochim. Acta, 34: 157-168.

Walter, L. M. \& J. S. Hanor, 1979a. Orthophosphate: Effect on the relative stability of aragonite and magnesian calcite during early diagenesis. J. Sed. Petrol. 49: 937-944.

Walter, L. M. \& J. S. Hanor, 1979b. Effect of orthophosphate on the dissolution kinetics of biogenic magnesian calcite. Geochim. Cosmochim. Acta, 43: 1377-1385.

Weinberger, L., 1955. Beiträge zur Pleistozänforschung in Österreich, Exkursionen durch das österreichische Salzachgletschergebiet und die Moränen des Irr- und Atterseezweiges des Traungletschers. Verh. Geol. B.-A., Wien, Sonderheft D: $7-40$.

Accepted 18 March 1986. 